\title{
MEMBANGUN KARAKTER BANGSA DENGAN NILAI-NILAI KEUTAMAAN DALAM BHAGAVAD GITA SUATU KAJIAN PUSTAKA ATAS KARYA NGAKAN PUTU PUTRA
}

\author{
Oleh \\ Diana Dewi Andayani \\ Tenaga Pendidik Mata Pelajaran PPKn pada SMPN 12 Denpasar
}

\begin{abstract}
Lately, characters become very serious conversation. Various Portals of Government Agencies which are associated with education makes the characters as the project theme of national seminars. In a variety of social media will very often be found articles related to the characters. This is because the Indonesian Government is anxious to see the reality of nation's community mental which is experiencing a crisis and moral degradation.

Cases of corruption and human tragedy that were done by those who are supposedly literate even become a spectacle on various TV stations. It encourages the government of Indonesia sought to reformulate the National Education Goals as outlined in UUSPN No. 20 of 2003 Article 3. That article states that education aims to develop students' potential to become a human of faith and piety to God Almighty, noble, healthy, knowledgeable, skilled, creative, independent, and become democratic and accountable citizens to the community and nationality. All are then formulated into 18 (eighteen) grains of the noble values of the nation then called the values of the character as a means to build the nation's character.

Although the Indonesian government has formulated 18 characters to build the nation's character, but various groups, community leaders and academics are still eager to participate to complement the Government's thoughts. This article shall discuss a book by national Hindu leaders, namely Ngakan Putu Putra, a comprehensive work explored in the literature that explores the Bhagavadgita which discusses 27 (twenty-seven) character value that gives hope for the realization of the nation's character.
\end{abstract}

Keywords: Improve, Quality, Character, Bhagavad Gita Virtues

\section{PENDAHULUAN}

Sejak beberapa tahun lalu, semangat dan nilai-nilai perjuangan yang diwariskan oleh para pendiri Negara Republik Indonesia tampak mulai memudar. Bersamaan dengan itu muncul juga kelompok sparatis bahkan kelompok teroris turut memperkeruh semangat integritas bangsa. Berbagai kerusuhan muncul di berbagai wilayah RI yang telah merusak dan menodai semangat persatuan dan kesatuan, hal mana disebabkan oleh berbagai konflik kepentingan. Selain berbagai konflik yang terjadi di masyarakat, dedikasi atau semangat pengabdian dari para abdi negara juga mengalami kemerosotan 
yang sangat tajam. Hal ini ditunjukkan oleh berbagai kasus korupsi yang dilakukan oleh para pejabatan negara. Berbagai upaya telah dilakukan oleh Pemerintah untuk menanggulangi berbagai konflik masyarakat untuk mengembalikan semangat integritas bangsa. Tetapi, tetap saja berbagai konflik, korupsi dan berbagai tindakan yang bertentangan dengan norma-norma hukum tetap terjadi di manamana. Disinyalir aspek penyelenggaraan pendidikan turut menjadi penyebab terjadinya degradasi bangsa. Artinya, aspek penyelenggaraan pendidikan yang lebih berorientasi pada kecerdasan intelektual dan hanya sedikit sekali berorientasi pada moral, agama dan kecerdasan spiritual. Akhirnya hal tersebut menyebabkan kecerdasannya disalahgunakan untuk tujuan korupsi dan manipulasi. Dipercaya atau tidak, diakui atau tidak, menyaksikan semakin maraknya tindak kejahatan korupsi dan berbagai tindak-tndak kejahatan kemanusiaan dilakukan oleh terpelajar, maka sudah pastilah sistem dan nilainilai pendidikan yang selama ini digunakan perlu ditinjau kembali atau direvisi.

Oleh karena itu Pemerintah RI berupaya merumuskan kembali Tujuan Pendidikan Nasional (TPN) sebagaimana dituangkan dalam UUSPN No 20 Tahun 2003 Pasal 3. Pasal itu menyatakan bahwa pendidikan bertujuan mengembangkan potensi didik agar menjadi manusia yang beriman dan bertakwa kepada Tuhan Yang Maha Esa, berakhlak mulia, sehat, berilmu, cakap, kreatif, mandiri, dan menjadi warganegara demokratis serta bertanggungjawab terhadap kemasyarakatan, dan kebangsaan. Semua itu dirumuskan menjadi 18 (delapan belas) butir nilai-nilai luhur sebagai modal membangun kembali karakter bangsa. Kedelapan belas nilai itu, yaitu: (1) religius, (2) jujur, (3) toleransi, (4) disiplin, (5) kerja keras, (6) kreatif, (7) mandiri, (8) demokratis, (9) rasa ingin tahu, (10) semangat kebangsaan, (11) cinta tanah air, (12) menghargai prestasi, (13) bersahabat, (14) cinta damai, (15) gemar membaca, (16) peduli lingkungan, (17) peduli sosial, dan (18) tanggung jawab ( $w w w$ perpustakaan kemdiknas.go.id). Itulah delapan belas nilai-nilai mulia karakter yang digali dari nilai-nilai spiritualitas Nusantara. Diharapkan nilai-nilai tersebut mampu membangun kembali karakter bangsa Indonesia yang belakangan ini mengalami kerapuhan. Walaupun Pemerintah RI telah menetapkan delapan belas nilai karakter yang harus digunakan sebagai modal pembangunan karakter bangsa, namun setiap komponen bangsa juga senantiasa tetap berkeinginan untuk berpartisifasi menawarkan konsep-konsep pembangunan karakter yang digalinya dari nilainilai ajaran agama dan spiritual yang dianutnya. Ada beberapa pakar intelektual dan tokoh agama telah menawarkan berbagai konsep dan nilai karakter, di antara sekian banyaknya tawaran konsep yang diberikan oleh para pakar, maka dalam tulisan ini ini dipilih buku dengan judul Membangun Karakter Dengan Keutamaan Bhagawas Gita karya tokoh Hindu tingkat nasional, yaitu Ngakan Putu Putra. Jika Pemerintah RI menetapkan 18 nilai karakter, maka Ngakan Putu Putra menyodorkan 27 (dua puluh tujuh) nilai keutamaan yang digali dalam ajaran Bhagavadgita. Ke dua puluh tujuh nilai keutamaan Bhagawad Gita tersebut adalah: (1) Kejujuran; (2) Kebenaran; (3) Keberanian; (4) Kepahlawanan; (5) Tahan Uji, (6) Ketabahan; (7) Ketetapan Hati atau Kekuatan Kehendak; (8) Hidup Sederhana; (9) Hidup Penuh Semangat; (10) Pengendalian Diri; (11) Kebijaksanaan Yang Mantap; (11) Tidak Mencari-cari Kesalahan Orang Lain; (12) Rendah hati, Bersahaja; (13) Tanpa-kekerasan; (14) Tidak Membenci; (15) Tidak Marah; (16) Tidak Serakah; (17) Kedermawanan / Kemurah-hatian; (18) Berterima Kasih; (19) Bersih, Murni, Suci; (20) Tarak, Pantangan Seksual; (21) Menundukkan Nafsu; (22) Kesabaran; (23) Pengampunan; (24) Welas Asih; (25) Pertemanan; (26) Kelemah- 
lembutan; (27) Damai/Tenang. Melalui pelaksanaan dua puluh tujuh nilai keutamaan Bhagavadgita secara sungguh-sungguh dalam proses pembangunan karakter bangsa, maka ada harapan besar bahwa bangsa Indonesia dikemudian hari akan menjadi bangsa yang terbesar dan terdepan dalam peradaban manusia.

\section{PEMBAHASAN}

Indonesia sebagai bangsa yang besar tidak perlu meratap menangisi kenyataan bahwa ada demikian banyak para terpelajar atau para intelektual dengan gelar kesarjanaan yang berderet, namun bersamaan dengan itu pula mereka melakukan tindakan-tindakan kejahatan yang bertentangan dengan normanorma agama dan norma-norma hukum. Adanya tudingan bahwa tindakan kejahatan yang dilakukan oleh para terpelajar atau para intelektual disebabkan karena kurikulum dan sistem pendidikan yang terlalu banyak menekankan kecerdasan intelek dan sangat sedikit memberi ruang terbentuknya moral yang baik, maka mau tidak mau kritik dan tudingan terhadap kurikulum tersebut segera direspon dan dilakukan perbaikan kurikulum. Sebagai salah satu Prof. Zuhdan K. Prasetyo seorang Guru Besar Pendidikan IPA, Jurusan Pendidikan Fisika pada Fakultas Matematika dan Ilmu Pengetahuan Alam Universitas Negeri Yogyakarta dalam makalahnya berjudul Generasi Emas 2045 sebagai Fondasi Mewujudkan Siklus Peradaban Bangsa Melalui Implementasi Kurikulum 2013 di Sekolah Dasar yang disajikan dalam Seminar Nasional Kurikulum 2013 di Universitas Tanjungpura Pontianak, hari Rabu, 16 April 2014 menguraikan bahwa: "Perubahan kirikulum sebagai bentuk pengembangan KTSP menjadi Kurikulum 2013 hingga kini menarik untuk didiskusikan. Apapun alasan isu perubahan itu wajar jika selalu diikuti dengan pro vs kontra. Di luar itu, masalah implementasinya pun luar biasa menarik untuk dicermati bahkan perlu pengawalan yang serius. Pengawalan yang serius terhadap implementasi kurikulum 2013 terutama dilakukan untuk menjamin terwujudnya Generasi Emas 2045. Generasi Emas yang disiapkan saat ini melalui implementasi Kurikulum 2013 diprogram untuk dapat mewujudkan pendidikan dasar yang bermutu. Melalui pendidikan dasar yang bermutu diyakini, bahwa Generasi Emas pada tahun 2045 mampu menunjukkan siklus kejayaan Bangsa ini akan terulang kembali, yaitu sebagai bangsa yang unggul peradabannya. Dengan kata lain Bangsa Indonesia diharapkan menjadi bangsa yang disegani oleh bangsabangsa lain karena kemajuan peradabannya yaitu berbudi luhur. Pendidikan, khususnya pendidikan di sekolah dasar diyakini berperan dalam membangun adab, budi pekerti luhur bangsa ini. Program dan metode dalam pendidikan atau kurikulum dan pembelajaran di sekolah dasar yang bagaimana dapat membangun peradaban Bangsa ini adalah diskusi yang hangat dilakukan dalam seminar nasional ini. Sebagai insan pendidikan, berharap melalui seminar nasional ini dapat memberikan sumbangan sekecil apapun sebagai wujud keikutsertaan dalam membangun peradaban bangsa, demi kejayaan anak, cucu penerus Bangsa Indonesia 31 tahun yang akan datang (2014: ii).

Demikianlah pemaparan Prof. Zuhdan K. Prasetyo seorang tokoh akademik dalam kata pengantar makalahnya. Sebagai bentuk partisifasi aktif yang dilakukan oleh umat Hindu, maka lahir juga pemikiran tokoh Hindu nasional, yaitu Ngakan Putu Putra yang menyodorkan dua puluh butir nilai-nilai mutiara "keutamaan" yang digali melalui penelitiannya terhadap pustaka suci Bhagavad Gita. Ke dua puluh nilai keutamaan Bhagavad Gita tersebut adalah sbb:

\section{Kejujuran (Arjavam):}

Nilai kejujuran (arjava) adalah modal utama dan pertama dalam pembangunan dan 
peningkatan kualitas karakter. Nilai kejujuran ini dapat ditemukan dalam Bhagawad Gita 18.42 yang berbunyi Samo damastapah saucam ksantirarjavam eva ca; jnanam vijnanam astikyam brahmakarma svabhavajam, yang artinya "pengendalian pikiran dan indera, kesederhanaan, kemurnian, ketabahan, dan juga kejujuran, pengetahuan, realisasi, percaya terhadap kehidupan sesudah kematian ini adalah jalan-jalan dari para brahmana yang lahir dari hakikat mereka sendiri'. Kata arjava juga diditemukan dalam sloka 13.7 dan 16.1. Ngakan Putu Putra menyatakan bahwa kejujuran adalah unsur pertama yang membentuk karakter bersama dengan beberapa keutamaan lain, seperti kecerdasan (jnana) dan keberanian (abhaya). Sebab kejujuran saja tidak mampu membentuk karakter yang kuat. Sebaliknya kecerdasan dan keberanian tanpa kejujuran akan merusak karakter.

Lebih lanjut Ngakan Putu Putra juga menyatakan bahwa kejujuran biasanya dikaitkan dengan kebenaran dan kebaikan. Seorang yang berkata jujur artinya dia mengatakan hal sebenarnya. Dan keduanya itu harus dikaitkan dengan kebaikan. Apa gunanya bicara jujur dan benar tetapi tidak membawa kebaikan? Pada umumnya berkata jujur dan benar pasti membawa kebaikan. Di atas ketidakjujuran akan tumbuh ketidakpercayaan, di atas ketidak-percayaan akan tumbuh kecurigaan dan kebencian. Di dalam masyarakat seperti itu, tidak akan ada pertemanan apalagi cinta dalam keluarga.

Lebih lanjut Ngakan Putu Putra juga menyatakan bahwa kejujuran adalah dasar dari suatu masyarakat yang baik, maju, sejahtera, beradab dan dihormati. Dalam masyarakat yang jujur perdagangan mereka akan maju. Kepada para pelaku perdagangan yang dilakukan oleh orang-orang jujur, maka masyarakat akan percaya terhadap kualitas atau harga yang ditawarkan. Orang-orang jujur walaupun melakukan kecurangan atau korupsi, maka tingkat korupsi mereka juga sangat rendah. Negara yang masyarakatnya jujur misalnya adalah Jepang, Singapura dan beberapa negara lain, tingkat korupsinya sangat kecil.

\section{Kebenaran (Satyam):}

Nilai kebenaran (satya) sebagai unsur kedua sebagai pembentuk karakter dapat ditemukan dalam Bhagavad Gita 16.2 dan juga Bhagavad Gita 16.3 yang berbunyi: ahiAsâ satyam akrodhah tyâga\% úântir apaiøunam dayâ bhûtecv aloluptvaA mârdavaA hrîr acâpalam. Artinya, 'Nonkekerasan, kebenaran, tidak kemarahan, renunsiasi, ketenangan/kedamaian, tidak memfitnah, welas asih kepada semua makhluk, tidak tamak, kelembutan, kerendahan hati, tidak berubah-ubah' adalah sifat-sifat dari mereka yang lahir dari kesucian'. Kata satyam juga ditemukan dalam Bhagawad Gita 10.4. Ngakan Putu Putra menguraikan bahwa kebenaran bersifat obyektif artinya, pernyataan itu sesuai dengan obyeknya. Misalnya mengatakan hal yang benar karena langit memang cerah dan bulan bersinar penuh. Ini mungkin dapat dikatakan kebenaran obyektif kondisional. Karena langit kadang-kadang gelap dan bulan bersinar setengah atau bahkan tidak tampak di langit. Ada kebenaran obyektif mutlak, misalnya, api itu panas, air cair, batu padat, atau bumi mengelilingi matahari.

Ngakan Putu Putra juga menyatakan bahwa ada kebenaran ilmiah, umumnya berupa teori yang merupakan hasil dari pengamatan empiris dan/atau kesimpulan akal, tetapi ini masih bersifat sementara, artinya sepanjang belum ditemukan kebenaran baru yang membuktikan kesalahan dari teori sebelumnya (falsifikasi). Lalu ada kebenaran agama yang berdasarkan keyakinan. Ini dibagi menjadi dua katageri, yaitu keyakinan rasional dan keyakinan tidak rasional (dogmatis). Yang pertama misalnya keyakinan akan hukum karma. Ini bisa dilihat secara empiris. Keyakinan dogmatis 
mengatakan itu adalah takdir yang telah ditetapkan secara sepihak dan sewenangwenang oleh Tuhan sebelum ia lahir ke dunia ini. Orang atheis mengatakan itu hanya kebetulan saja. Atau keyakinan bahwa hanya karena beriman akan suatu agama, suatu kitab suci, tidak perduli apapun perbuatannya, dikatakan orang tersebut akan selamat atau masuk sorga. Ini tidak sesuai dengan kenyataan dan hati nurani manusia yang sehat.

Oleh karena itu, Ngakan Putu Putra juga menyatakan bahwa kejujuran belum tentu kebenaran. Orang yang mengatakan secara jujur bahwa ia suka selingkuh, suka melakukan kekerasan atau suka membunuh (seperti yang dikatakan oleh Abubakar Sekhau, pemimpin Boko Haram di Nigeria); ia berkata jujur tentang sesuatu yang tidak benar. Satyam merupakan konsep penting dan kebajikan utama dalam agama Hindu. Dalam pustaka suci $R g$ Weda yang diperkirakan berasal dari milenium ke 5 SM, memberikan pembahasan awal tentang satya atau kebenaran. Hal ini dapat dilihat, misalnya, dalam baris kelima dan keenam, di dalam Rg Weda. Satya secara harfiah berarti kebenaran, realitas, hakikat kenyataan. Kata ini juga mengacu pada keutamaan dalam agama Hindu, mengacu pada kejujuran dalam pikiran, ucapan dan tindakan seseorang. Dalam Yoga, satya adalah salah satu dari lima Yama, berbudi luhur menahan diri dari kebohongan dan distorsi realitas dalam perkataan dan tindakan. Dalam bahasa Sansekerta satya juga berarti sebagai "kebenaran mutlak". Satya adalah tema sentral dalam Weda.

\section{Keberanian (Abhayam):}

Kata keberanian atau tidak takut (abhaya) adalah unsur ketiga pembentuk karakter dapat ditemukan dalam Bhagavad Gita 16.1, 16.3 juga dalam Bhagavad Gita 10.4. Dalam Bhagavad Gita 16.1 dinyatakan: Abhayam sattva samsuddhih jnana yoga vyavastithtih; danam damasca yajnasca svadyayastapa arjavam". Artinya, Keberanian, kemurnian hati, ketekunan dalam ilmu pengetahuan, dan yoga, pemberian derma, pengendalian indera, yajna atau pengorbanan, mempelajari pustaka suci, berhemat, kejujuran atau kelurusan hati'. 'Ini adalah sifat-sifat dari mereka yang lahir dari kesucian' (16.3). Nilai keberanian (abhaya) juga terdapat dalam sloka 10.4. Ngakan Putu Putra menyatakan bahwa setelah kejujuran dan kebenaran, keberanian adalah unsur ketiga yang membentuk karakter. Orang yang jujur, bila tidak ada keberanian, bisa jadi tidak akan berkata benar, atau berbuat benar bila ia ada di dalam situasi yang tidak menguntungkan, bagi kepentingan atau jiwanya. Oleh karena itu, kejujuran memerlukan bantuan keberanian. Tanpa keberanian orang jujur juga tidak bisa maju, karena takut memikul risiko. Sebaliknya keberanian dan kepintaran memerlukan kejujuran.

Ngakan Putu Putra menyatakan hanya keberanian saja yang dapat menghasilkan sifat alamiah dari seseorang. Ketakutan menghalangi semua sifat baik pada manusia. Jadi, abhayam adalah keutamaan pertama yang harus dikembangkan oleh setiap orang yang merupakan bagian dari kategori daivi sampat. Hanya orang berani yang mampu melakukan hal-hal besar, bukan orang pengecut. Orang yang berani saja bisa bersikap tulus. Keberanian tidak hanya diperlukan di medan perang tetapi di dalam berbagai bidang kehidupan. Mau mendirikan usaha perlu keberanian; keberanian untuk melawan ketakutan akan gagal. Bahkan mau mencari pasangan hidup pada waktu muda, juga perlu keberanian; keberanian untuk melawan ketakutan ditolak.

\section{Kepahlawanan (Sauryam):}

Nilai kepahlawanan sebagai unsur keempat pembentuk karakter dapat ditemukan dalam Bhagavad Gita 18.43 seperti terlihat dalam sloka berikut: ceauryamì tejo dhròtir dâksòyamì yuddhe câ apy apalâyanam; 
dânam îúvara-bhâvaú ca ksòâtramì karma svabhâvajam. Artinya 'Kepahlawanan, kekuatan, tekad, kecerdikan, keberanian dalam pertempuran, kemurahan hati dan kepemimpinan adalah kualitas alami dari pekerjaan untuk para Ksatriya'. Ngakan Putu Putra menyatakan bahwa seorang pahlawan adalah orang yang rela mengabdikan hidupnya untuk kebenaran suci dan kebenaran batin serta berbagi visinya dengan seluruh dunia. Hal ini adalah definisi seorang laki-laki sejati: seorang makhluk yang mendalam dan spiritual, menjalani hidupnya dengan kebenaran suci. Semua jenis pahlawan secara intrinsik dibentuk dari bahan yang sama; yang diberikan jiwa yang besar, terbuka untuk Makna Suci dari Hidup, maka pria seperti ini yang pantas untuk berbicara tentang kepahlawanan, menyanyikan kepahlawanan, berjuang dan bekerja untuk kepahlawanan.

Ngakan Putu Putra menyatakan bahwa pahlawan adalah orang yang membentang melintasi zaman, ia berbicara kepada generasi di luar dirinya sendiri. Pahlawan adalah wujud kedewasaan, juga perwujudan dari laki-laki utama. Pahlawan adalah orang besar, yang kepadanya setiap orang melihat dan merasa kagum. Pemujaan terhadap Pahlawan adalah alamiah, karena kita menyadari bahwa orangorang ini mewujudkan kebesaran yang diperjuangkan oleh semua orang lainnya. Unsur pertama dari kepahlawanan adalah keberanian dalam segala bidang - tetapi kepahlawanan saja tidak cukup, karena keberanian sering disalahgunakan untuk berbuat kerusakan bagi masyarakat. Para begal, rampok dan pembunuh bayaran adalah orang-orang yang mempunyai keberanian, tetapi tidak ada yang menyebut mereka pahlawan. Orang yang pengecutpun, bisa menjadi pahlawan, bila keadaan memaksanya, seperti kata Swami Vivekananda. Unsur penting dari kepahlawanan, selain keberanian, adalah kerelaan berkorban: waktu, tenaga, pikiran, harta benda bahkan nyawa untuk orang-orang lain atau untuk kepentingan yang lebih besar dari diri kita sendiri.

\section{Tahan Uji, Ketabahan (Titiksa):}

Nilai tahan uji atau ketabahan (titiksa) sebagai unsur kelima pembentuk karakter dapat ditemukan dalam Bhagavad Gita 2.14 sebagaimana dinyatakan: matrasparsastu kaunteya sitoshna-sukha-duhkha-dah; agamapayino "nityah tams titiksha sva bharata. Artinya: O putra Kunti, penampakan non-permanen dari kebahagiaan dan penderitaan, dan hilangnya mereka pada waktunya, seperti penampakan dan hilangnya musim dingin dan musim panas. Mereka muncul dari persepsi indera, O keturunan Bharata, dan seorang harus belajar untuk menanggungnya tanpa terganggu'. Ngakan Putu Putra menyatakan bahwa kata "tahan uji" sebagaimana disebutkan dalam sloka di atas adalah "kemampuan untuk menanggung kenyataan tanpa ada perasaan terganggu terhadap kebahagiaan atau penderitaan yang datang secara silih berganti" seperti datangnya musim dingin dan musim panas yang saling menggantikan.

Tahan uji juga berarti ketahanan untuk menghadapi godaan. Dan godaan itu banyak sekali ragamnya, misalnya yang berkaitan dengan kama, harta dan takhta. Sudah menjadi pendapat umum bahwa orang yang mampu menahan diri terhadap godaan akan berhasil dalam hidupnya dibandingkan dengan orang yang tidak. Sering tersiar dan terdengar berita di media massa tentang pejabat Negara yang ditangkap dan kemudian dipenjarakan karena korupsi. Mereka adalah contoh orang-orang yang tidak tahan uji menghadapi godaan uang, kekuasaan, dan wanita.

Ngakan Putu Putra menyatakan bahwa titiksha sebagai daya tahan (tahan uji) tanpa kecemasan atau ratapan dan tanpa bantuan eksternal, Sankara mengartikan titiksha sebagai sarana untuk penyelidikan atau pencarian 
Brahman, karena pikiran yang tunduk pada kecemasan dan ratapan tidak layak untuk melakukan pencarian Brahman semacam ini. Swami Vivekananda menjelaskan bahwa kesabaran dari semua penderitaan, tanpa memikirkan menolak atau mengusirnya keluar, bahkan tanpa perasaan sakit dalam pikiran, atau penyesalan apapun adalah titiksha.

\section{Ketetapan Hati atau Kekuatan Kehendak (Sankalpa):}

Nilai 'ketetapan hati' atau 'kekuatan kehendak' sebagai unsur keenam pembentuk karakter dapat ditemukan dalam Bhagavad Gita 6.2, sebagaimana dinyatakan: yam sannya samitiprahuh yogam tam viddhi pandava; na hya sannyastasankalpo yogi bhavati kascana. Artinya: 'Apa yang disebut penolakan (sannyasa) harus diketahui hal itu sama dengan yoga, atau menghubungkan diri dengan Yang Agung, $\mathrm{O}$ putra Pandu, karena seorang tidak pernah bisa menjadi seorang yogi kecuali dia membuang keinginan untuk kepuasan indera' . Ngakan Putu Putra menyatakan bahwa sankalpa memiliki duaarti:"negative" dan "positif'. Dalam sloka 6.2 di atas sankalpa adalah akar dari keinginan yang harus dibuang bila orang ingin menjadi seorang yogi. Bila sankalpa tidak dibuang maka seseorang tidak akan dapat menjadi seorang yogi. Sankalpa artinya keinginan yang keluar, "saya harus punya ini, saya harus punya itu". Karena faktor sankalpa itu seseorang menjadi sangat terikat pada sesuatu, itulah sebabnya harus dibuang jika ingin mendapatkan rasa kebebasan seperti apa yang dirasakan oleh yogi. Sankalpa membawa kepada keinginan-keinginan, kemudian keingian-keinginan melahirkan berbagai jenis aktivitas, termasuk kehidupan delusif(khayalan) yang sangat sering dialami oleh berbagai lapisan masyarakat. Jadi bila seseorang dipenuhi oleh sankalpa ini, maka seseorang tidak dapat mengendalikannya, orang akan menjadi budak sankalpa atau keinginan. Ini pengertian sankalpa dalam makna negatif.

Ngakan Putu Putra menyatakan bahwa sankalpa dalam pengertian positif dapat dapat diartikan sebagai konsepsi, gagasan atau pengertian yang terbentuk dalam hati atau pikiran, sumpah khidmat atau tekad untuk melakukan, niat yang pasti, kemauan atau kehendak yang kuat (resolution, determination). Dalam istilah praktis, kata sankalpa secara positif berarti satu tekad yang bulat untuk melakukan atau mencapai; secara psikologis maupun filosofis, itu adalah langkah praktis pertama di mana sensitivitas dan potensi pikiran ditingkatkan; ini dikenal sebagai kapasitas untuk memanfaatkan kemauan dan alat untuk fokus dan menyelaraskan segala sesuatu yang kompleks dalam tubuh dan pikiran. Jadi sankalpa itu ada dua jenisnya. Keinginan yang liar tak terkendali, umumnya pada obyek-obyek indera, adalah buruk, karena bisa membawa keterikatan bahkan celaka. Tetapi keinginan untuk tujuan-tujuan bermakna, khususnya yang bersifat dharma semuanya baik. Keinginan untuk moksa (mumuksutva) bahkan sangat diajurkan.

\section{Hidup Sederhana (Tapasya):}

Nilai hidup sederhana (tapasya) sebagai unsur ketujuh pembentuk karakter dapat ditemukan dalam Bhagavad Gita 17.5-6 sebagaimana dinyatakan: aúâstra-vihitamì ghorami tapyante ye tapo janâhò; dambhâhañkâra samìyuktâhòkâma-râgabalânvitâhò. karsòavantahò úarîra-sthamì bhûta-grâmam acetasahò mâmì caivântahò úarîra-sthamì tân viddhy âsura-nioecayân. Artinya: Bagi mereka yang menjalani pertapaan berat dan penebusan dosa tidak dianjurkan dalam kitab suci, melakukannya karena kesombongan dan egoisme, yang didorong oleh nafsu dan keterikatan, yang bodoh dan yang menyiksa unsur materi tubuh serta Sang Paramatma yang tinggal di dalam, ketahuilah 
itu sebagai bersifat keraksasaan'. Kata tapah, tapas atau tapasya disebut empat belas kali dalam Bhagawad Gita yaitu:7.9; 10.5; 16.1; 17.5,7, 14-19, 28; dan 18.5, 42.

Ngakan Putu Putra menjelaskan bahwa kata apas berarti meditasi mendalam, upaya untuk mencapai realisasi diri, kadang-kadang melibatkan kesendirian. Kata ini berasal dari akar kata tap yang berarti 'panas' dari kebakaran, cuaca, api yang membakar, bersinar, penebusan dosa, rasa sakit, penderitaan, matiraga. Dalam Weda, gabungan kata yang berkaitan dengan tapas banyak digunakan untuk menjelaskan beberapa konsep spiritual yang berkembang melalui panas atau energi batin, seperti meditasi, proses untuk mencapai pengamatan dan wawasan khusus, ekstasi spiritual seorang yogi. Kata tâpasa berarti seorang praktisi pertapaan, seorang pertapa'. Dalam konteks tertentu, istilah ini juga digunakan dengan arti penebusan dosa, penderitaan, hidup sangat sederhana dengan aktivitas religius.

Lebih lanjut Ngakan Putu Putra menyatakan bahwa dalam tradisi yoga tapas adalah api yang membakar di dalam yang diperlukan oleh sanyasin untuk mencapai tujuan pencerahan yang sangat sulit. Tapas adalah upaya sungguh-sungguh untuk mendorong pengendalian diri, menyatukan pikiran dan fokus, kesederhanaan, kebijaksanaan, integritas. Hal ini digunakan untuk mengembangkan dan mendisiplinkan tubuh, pikiran dan karakter; pengendalian pikiran; kepuasan semua keinginan. Melalui disiplin tubuh diharapkan ucapan menjadi benar, mengatakan hanya kebenaran, pikiran yang benar, tidak melakukan kekerasan. Bertindak benar, mencintai semua ciptaan, melaksanakan pengabdian kepada Tuhan, mengembangkan kemampuan untuk tetap tenang dan seimbang dalam setiap situasi, tindakan tanpa motif egois atau memikirkan hadiah atau balasan, dengan keyakinan yang tak tergoyahkan kepada Tuhan. Itulah tapas, dengan melaksanakan secara sungguh-sungguh nilai tapas ini, maka tidak akan membuat seseorang jatuh dalam kejahatan apapun.

\section{Hidup Penuh Semangat (Tejah):}

Nilai karakter yang 'hidup penuh semangat' sebagai unsur kedelapan pembentuk karakter dapat ditemukan dalam Bhagavad Gita 18.43 sebagaimana dinyatakan: ceauryamì tejo dhròtir dâksòyamì yuddhe câpy apalâyanam; dânam îúvara-bhâvaú ca ksòâtramì karma svabhâva-jam. Artinya: 'Kecakapan, semangat, penuh ketabahan atau bertekad, menggunakan akal, memiliki keberanian dalam pertempuran, kemurahan hati dan kepemimpinan adalah kualitas alami dari pekerjaan untuk para ksatriya'. Ngakan Putu Putra menyatakan bahwa Bhagawad Gita mengajarkan agar manusia hidup dengan penuh semangat, penuh vitalitas, dan energik. Tejo atau tejah berarti: Kekuatan aktif; energi fisik atau mental yang sehat atau kekuasaan; vitalitas; kegiatan energik; energi; intensitas: kekuatan pertumbuhan yang sehat dalam hal hidup atau organisme, seperti tanaman; kekuatan aktif atau efektif.

Secara singkat tejo dapat diartikan sebagai hidup yang penuh vitalitas (the strenuous life atau energetic life). Orang yang hidup penuh semangat tanpa mempedulikan untung atau rugi, ia akan memiliki semangat juang seperti para ksatriya yang tidak takut menghadapi medan perang. Seorang dengan mental ksatriya tidak akan takut menghadapi kekalahan dalam segala usahanya dengan tetap berupaya meraih kesuksesan. Orang dengan mental ksatriya tidak akan melakukan kecurangan atau kejahatan.

\section{Pengendalian Diri (Dama):}

Nilai karakter dalam bentuk 'pengendalian diri' sebagai unsur kesembilan pembentuk karakter dapat dijumpai dalam Bhagavad Gita 16.1;16.3 dan 18.42 sebagaimana dinyatakan: abhayaA sattva sanohuddhir jñ̂nna yoga 
vyavasthiti\% dânaA damaúh cha yajñaúh cha svâdhyâyas tapa ârjavam. Secara keseluruhan dapat diartikan sbb: 'Keberanian, kemurnian hati, ketekunan dalam ilmu pengetahuan, dan yoga, pemberian derma, pengendalian indera, yajna atau pengorbanan, mempelajari susastra suci, berhemat, kejujuran atau kelurusan hati' Semua itu adalah sifat-sifat dari mereka yang lahir dari kesucian'.

Ngakan Putu Putra menguraikan bahwa pengendalian diri tidak harus menunggu sampai seseorang memiliki pengetahuan tentang dirinya, karena hal itu akan menjadi sangat terlambat. Oleh karena itu pengendalian diri harus mulai sejak anak-anak, dengan cara penerapan disiplin yang dikenakan dari luar. Sebagai contoh seorang anak harus dibiasakan bangun pagi dengan sendirinya. Bila terlambat bangun, ia diberi sanski, misalnya tidak diberi uang jajan. Tidak mementingkan diri sendiri, belajar bersimpati pada teman atau saudara yang kesulitan. Seorang anak juga tidak boleh dimanja, tidak semua keinginannya dipenuhi, anak harus belajar untuk menerima kekecewaan, tanpa itu ia tidak akan memiliki pengendalian diri. Dari kecil anak itu harus diajarkan fakta kehidupan bahwa tidak semua keinginannya nanti setelah dia dewasa akan dapat terpenuhi.

\section{Kebijaksanaan yang Mantap (Samah samya):}

Nilai karakter yang mengandung nilai 'kebijaksanaan yang mantap' sebagai unsur kesepuluh pembentuk karakter dapat ditemukan dalam berbagai sloka Bhagavad Gita dengan jumlah yang cukup banyak sebagaimana dinyatakan Bhagavad Gita 2.8 sebagai berikut: sukha-duhòkhe same kròtvâ lâbhâlâbhau jayâjayau; tato yuddhâya yujyasva naivamì pâpamavâpsyasi. Artinya: Setelah membuat penderitaan dan kesenangan, keuntungan dan kerugian, kemenangan atau kekalahan, sama, maka libatkan dirimu sendiri dalam pertempuran atau perjuanagan. Dengan demikian kamu tidak akan menderita kemalangan'. Ngakan Putu Putra menyatakan bahwa kata samah samya disebut sebanyak 22 kali dalam Bhagawad Gita, yaitu pada: 2.15;38, 48; 4.22; 5.3, 7, 18-21; 6.7, 9; 13, $29,30,32$; $9.28 ; 12.13,14,18-19 ; 13.27-$ $28 ; 18.54)$.

Sloka-sloka di atas menanamkan nilai kepada manusia agar setiap manusia mengembangkan konsep kesamaan, yaitu sama-sama berasal dari Tuhan dan sama-sama diresapi oleh Tuhan. Hal ini sejalan dengan konsep ketuhanan menurut Upanisad, yaitu konsep ketuhanan pantheisme (monisme), yaitu Tuhan ada di dalam dan di luar ciptaan (imanen dan transenden). Singkatnya panteisme mengajarkan tentang konsep Tuhan yang ada di dalam ciptaan, menyatukan setiap ciptaan, menjadikan semua makhluk satu keluarga. Konsep ketuhanan seperti ini menjauhkan manusia dari tindakan kejahatan kepada mahluk lain, karena disadari sebagai satu kesatuan.

\section{Tidak Mencari-cari Kesalahan Orang Lain (Apaisunam):}

Nilai karakter yang bermakna 'tidak mencari-cari kesalahan orang lain' (apaisuna) sebagai unsur ke sebelas pembentuk karakter dapat ditemukan dalam Bhagavad Gita 16.2,3 sebagaimana dinyatakan: ahimisâ satyam akrodhas tyâgahò úântir apaiúunam; dayâ bhûtesòv aloluptvamialoluptvamì mârdavamì hrîr acâpalam. Artinya: 'Anti kekerasan; mencintai kebenaran; bebas dari kemarahan; mampu melakukan penolakan terhadap yang buruk; memiliki ketenangan; keengganan untuk saling menuduh atau tidak mencari-cari kesalahan orang lain; welas asih untuk semua makhluk hidup; bebas dari ketamakan; kelembutan; kesopanan; tekad atau determinasi'. Semua itu adalah sifat-sifat dari mereka yang lahir dari kesucian'(16.3)

Salah satu contoh sikap mencari-cari 
kesalahan, sebagaimana ucapan Hamzah Haz yaitu wakil Presiden RI dikutip oleh Ngakan Putu Putra, bahwa ia menyatakan: "Saya sudah katakan berkali-kali bahwa di Indonesia itu tidak ada teroris." Karena pada waktu itu Hamzah Haz mengatakan hal itu sebagai wakil Presiden RI karena itu ucapannya menjadi penting. Sebelumnya, telah terjadi pengeboman terhadap beberapa gereja di malam Natal pada tahun 2000. Hendropriyono, ketua BIN mensinyalir bahwa Poso telah dijadikan tempat latihan teroris. Namun ketika bom meledak di Legian, Kuta, tanggal 12 Oktober 2002, yang menewaskan 202 orang, dan melukai lebih dari 300 orang, Hamzah buru-buru meralat pernyataannya. Ia pun harus mengakui adanya terorisme di Indonesia. "Ini adalah tindakan teroris," tuduh Hamzah. Namun Hamzah masih bisa ngeles. "Cuma sampai saat ini belum ada yang terkait dengan Islam radikal seperti $\mathrm{Abu}$ Bakar Ba' asyir, Ja' far Umar Thalib, Habib Rizieq," kilah Hamzah.

Ngakan Putu Putra kembali mengutip kata-kataHamzah Haz yang dianggapnya selalu beruapaya mencari kambing hitam untuk disalahkan. Bagaimana dengan adanya tuduhan bahwa bom Bali adalah hasil rekayasa Amerika Serikat? "Pasti ada rekayasa, tapi tidak tahu dari mana," jawab Hamzah. (detikcom, 15/10/ 2002). Ngakan Putu Putra juga mengutip pernyataan Emha Ainun Nadjib, penyair dan budayawan kondang, lebih tegas dengan tuduhan rekayasa ini. Ia menunjuk hidung Amerika dan Israel. Najib, dari halaman sebuah pura di Kuta, dengan dramatis mengatakan, bom itu dilakukan agen-agen Yahudi dan AS. "Mula-mula terdengar ledakan kecil, kemudian terdengar ledakan dahsyat. Wuuuus!!! Itu hanya mungkin dilakukan oleh negara yang memiliki teknologi canggih", begitu kira-kira dia berkata, seperti orang yang sedang berdeklamasi, dengan penuh gaya, di tengah tragedi yang hebat. Bom kecil itu mungkin buatan domestik, tetapi bom besar pasti dari luar negeri. Jadi ada kerja sama antara pelaku bom kecil (Amrozi dkk) dengan pelaku bom besar, CIA (agen rahasia AS) dan Mosad (agen rahasia Israel)?

Akhirnya, tulis Ngakan Putu Putra salah seorang pelaku bom itu, Ali Imron (Ale), marah karena keahliannya, tidak diakui oleh sesama anak bangsa; lalu membuat pengakuan dengan bangga bahwa bom itu hasil karyanya bersama saudara-saudaranya, Amrozi, Mukhlas yang berprofesi sebagai guru pesantren di desa kecil di Tenggulun, Jawa Timur dan Iman Samudera, juga guru agama dari Banten. Setelah Ali Imron membuat pengakuan yang mengejutkan itu, Nadjib tetap tidak percaya, ia bergeming dengan teori konspirasinya.

\section{Rendah hati, Bersahaja (Aminatvam/ Adambitvam):}

Nilai karakter yang bermakna 'rendah hati' atau 'bersahaja' (aminatwam atau adambitwam sebagai unsur ke dua belas dapat ditemukan dalam Bhagavad Gita 13.7 dan 13.11 sebagaimana dinyatakan: Amanitvam adambhitvam ahimsa ksantirarjavam; acaryo pasanam saucam shairyam atmavinigrahah. Artinya: Kerendahan hati, bersahaja, non-kekerasan, kesabaran, kejujuran, pelayanan kepada guru, kemurnian atau kesucian, kemantapan, pengendalian diri'. Semua ini dinyatakan sebagai ilmu pengetahuan' (13.11). Nilai ini oleh Ngakan Putu Putra dinyatakan telah menjadi slogan hidup orang Bali, yaitu slogan "Ede ngaden awak bise, depang anake ngadanin.

Efek negative dari kesalah pengertian terhadap slogan ini telah membuat kita orang Bali tidak bisa maju. Bait geguritan ini membuat kita rendah diri," kata seorang teman yang menjadi aktivis dan pengacara. Jadi mestinya bagaimana agar kita maju? "Kita harus merasa dan mengaku bisa. Kalau tidak berasal dari sendiri mengatakan diri kita bisa, siapa lagi?" Ini adalah salah mengartikan slogan mulia itu. 
Seharusnya rendah hati adalah nilai yang menghantarkan seseorang percaya diri sesuai dengan kapasitasnya.

\section{Tanpa-kekerasan (Ahimsa):}

Nilai karakter yang 'tanpa kekerasan' (ahimsa) sebagai unsur ke tiga belas dapat ditemukan dalam sloka Bhagavadgita 10.5, dan 13.7 serta 16.2. Dalam sloka Bhagavad Gita 10.5 dinyatakan: Ahimsa samata tustih tapo danam yaso'yasah; bhavanti bhava bhutanam matta eva prthagvidhah. Artinya: 'Non-kekerasan, memiliki sikap yang sama terhadap suka dan duka, puas atas apa yang dimiliki, sederhana (austerity), murah hati, nama baik (juga) nama buruk, sebab semua jenis kualitas yang berbeda muncul dari Aku saja'.

Ngakan Putu Putra menulis bahwa apa yang disebut ahimsa ini telah dicontohkan oleh Gandhi bahkan telah didokumenkan dalam bentuk film. Adegan paling menggetarkan dari film "GANDHI" yang disutradarai oleh Sir Richard Attenborough (1982) adalah ketika sekitar 2.500 demonstran damai dipimpin oleh penyair Sarojini Naidu, bergerak maju secara berbaris untuk menduduki Dharasana Salt Works, tempat pembuatan garam milik penjajah Inggris. Mereka bergerak dalam tiga baris, maju melangkah mantap, dipukuli oleh polisi Inggris yang terdiri dari orang-orang India, jatuh tersungkur ke tanah, diambil oleh relawan lain, untuk dirawat. Lalu yang di belakangnya maju lagi, dipentung oleh polisi, jatuh pingsan bahkan ada yang meninggal. Tetapi barisan ini terus maju tanpa gentar dan tidak melawan, sampai semua mereka tergeletak di tanah. Adegan ini menggambarkan secara visual dengan jelas apa yang dimaksud oleh filosofi perjuangan tanpa kekerasan (satyagraha). Siap menerima kekerasan tanpa melakukan kekerasan.

Lebih lanjut Ngakan Putu Putra menyatakan bahwa keutamaan ahimsa telah menjadi terkenal di seluruh dunia, berkat Gandhi. Gandhi mempergunakan filosofi menjadi metode untuk memperjuangkan kemerdekaan India dari penjajahan Inggris. Ini suatu yang sangat unik. Biasanya kemerdekaan suatu bangsa diperoleh melalui pejuangan bersenjata, seperti yang dilakukan oleh bangsa Indonesia dan Vietnam, atau diberikan sebagai hadiah seperti yang diperoleh oleh bangsa Malaysia dan Singapura. Tetapi kemerdekaan India diperoleh melalui pejuangan non kekerasan yang dipelopori oleh Mahatma Gandhi untuk kurun waktu yang panjang, dimulai sejak dia kembali dari Afrika Selatan pada tahun 1915 sampai tahun 1947, ketika Inggris pergi dari India. Gandhi adalah orang pertama dalam sejarah manusia yang memperpanjang prinsip antikekerasan dari individu ke wilayah sosial dan politik." Sementara para sarjana berbicara tentang ide tanpa nama atau gerakan, Gandhi adalah orang yang datang dengan itu dan menggabungkan ide-ide terkait yang berbeda di bawah satu konsep: Satyagraha.

Selanjutnya Ngakan Putu Putra mengakhiri ulasan ahimsa-nya dengan menyatakan bahwa kebenaran dan antikekerasan adalah setua gunung-gunung. Agar ahimsa menjadi kuat dan efektif, harus dimulai dengan pikiran, tanpa itu ia akan menjadi non-kekerasan dari orang yang lemah dan juga pengecut. Seorang pengecut adalah orang yang tidak memiliki keberanian ketika menghadapi situasi berbahaya dan tidak menyenangkan dan mencoba untuk menghindarinya. Seorang tidak bisa mempraktikkan ahimsa dan pada saat yang sama menjadi seorang pengecut. Antikekerasan yang sejati dipisahkan dari rasa takut. Gandhi merasa kepemilikan senjata adalah pengecut atau kurangnya keberanian.

\section{Tidak Membenci (Advesta, Adroho)}

Nilai karakter yang bermakna 'tidak membenci' sebagai unsur ke empat belas dapat diketemukan dalam sloka Bhagavad Gita 12.13-14 yang berbunyi: Advesta sarva bhutanam maitrah karuna eva ca; nirmamo 
nirahankarah sama duhka sukhah ksami. santusòtòahò satatamì yogî yatâtmâ dròdòha-niocayahò mayy arpita-manobuddhir yo mad-bhaktahò sa me priyahò Artinya: 'Dia yang tidak membenci makhluk apapun, berteman dan welas asih terhadap semua, yang bebas dari perasaan "aku dan milikku", sama pikirannya dalam suka dan duka, sabar, toleran, selalu puas, menguasai diri, dan terlibat dalam pelayanan bhakti dengan tekad, pikiran dan kecerdasan dipusatkan pada-Ku, maka pemuja-Ku yang seperti itu sangat dekat untuk-Ku. Sloka di atas dengan jelas menyatakan bahwa Sri Krishna avatar sebagai perwujudan Tuhan yang menjelma menjadi manusia menekankan untuk tidak membenci apa dan siapa saja (sarva bhutanam $=$ segala mahluk).

Sumber konflik terjadi karena kebencian, kebencian muncul karena menganggap orang lain salah dan terkutuk; dan hanya diri sendiri yang paling benar. Lebih parah lagi jika menganggap bahwa yang salah itu harus dibinasakan. Di dunia dan di Indonesia, sejak lama secara diam-diam tanpa disadari sesungguhnya telah terbentuk tradisi yang kurang baik, yaitu tradisi menghina kepercayaan orang lain secara legal melalui Ilmu Perbandingan Agama. Selain buku-buku teks untuk perkuliahan, seperti "Empat Kuliyah Agama Islam" oleh professor Rasjidi, guru besar Studi Islam di Fakultas Hukum Universitas Indonesia, dan buku-buku pelajaran yang sengaja memperkenalkan dan mengkontraskan dikotomi antagonistik, seperti terminologi “Agama Langit" vs "Agama Bumi”, hal ini adalah ujaran kebencian yang memakai kaos ilmiah. Selain itu ada juga contoh lainnya terjadi ujar kebencian yang sangat kasar, seperti diucapkan oleh seorang ustaz yang mengaku keturunan Brahmana dan sarjana agama Hindu, yang ternyata palsu. Tetapi, dia itu aman-aman saja. Sikap beragama semacam ini tidak patut dicontoh oleh generasi bangsa yang dicalonkan akan menjadi Generasi Emas tahun 2045.

Ngakan Putu Putra menyakan bahwa ujaran kebencian juga pernah menghebohkan dunia pendidikan pada Bulan Maret 2015. Sebab, ternyata kebencian justru diajarkan secara resmi pada murid-murid SMP/SMA sebagaimana termuat dalam buku pendidikan Agama Islam, untuk kelas XI SMA, sebagai bahan ajar Kurikulum 2013. Dalam buku tersebut dinyatakan bahwa orang yang tidak beragama Islam dapat dibunuh. Menteri Pendidikan dan Kebudayaan menyatakan kaget dan Menteri Agama dalam wawancara dengan sebuah stasiun TV Jakarta berkata dengan tegas akan mengusut dan mengambil langkah hukum terhadap penulis buku tersebut. Tetapi sampai sekarang, tidak terdengar lagi tindaklanjut dari ancaman kedua menteri tersebut. Mungkin mereka mengalami dilemma, sebab buku tersebut bukan karangan penulisnya. Ia mengambil sumber rujukan dari ajaran Wahabi yang dicetuskan tokoh pembaharu Islam asal Arab Saudi, yaitu Muhammad bin Abdul Wahab (1703-1787). Ajaran Wahabi ini memang membenarkan dan mengajarkan bahwa selain Islam boleh dibunuh. Ajaran Wahabi ini menjadi faham resmi dari Kerajaan Arab Saudi. Salah satu pendapat Muhammad bin Abdul Wahab yang dikutip dalam halaman buku tersebut adalah: "Yang boleh dan harus disembah hanyalah Allah SWT, dan orang yang menyembah selain Allah SWT telah menjadi musyrik dan boleh dibunuh" (Tempo.co, 20-21 Maret 2015).

Ajaran Wahabi di atas benar-benar sangat berbeda dengan ajaran Sri Krishna, jika Wahabi mengajarkan membunuh selain Islam, maka Sri Krishna menyatakan jangan membenci atau tidak boleh membenci apa dan siapa saja. Untung saja buku tersebut cepat terdeteksi oleh Pemerintah Indonesia. Jika seandainya buku tersebut sudah diajarkan bertahun-tahun, maka berapa besar kebencian 
generasi terpelajar Islam kepada umat yang non-Islam. Inilah fakta dunia pendidikan Indonesia yang harus diwaspadai.

\section{Tidak Marah (Akrodah):}

Nilai karakter yang bermakna 'tidak marah' (akrodah) sebagai unsur ke lima belas dapat ditemukan dalam sloka Bhagavad Gita 16.21 sebagaimana dinyatakan: trividhami narakasyedamì dvâramì nâuanam âtmanahò; kâmahò krodhah tathâ lobhah tasmât etat trayami tyajet. Artinya: 'Ada tiga macam pintu gerbang penghancuran sang diri, yaitu: nafsu, kemarahan dan keserakahan; oleh karena itu, seseorang harus meninggalkan ketiganya ini'. Ngakan Putu Putra menyatakan bahwa selain sloka di atas itu, akrodah juga disebut dalam sloka Bhagavad Gita 16.2. Alasan mengapa kemarahan harus ditinggalkan atau dihindari? Karena kemarahan menyebabkan kebingungan, dari kebingungan kemudian ingatan terganggu. Karena terganggunya ingatan maka hilanglah segala logika dan kebijaksanaan. Karena hilangnya kebijaksanaan, maka seseorang akan tersesat (Bhagavad Gita 2.63).

Ngakan Putu Putra menyatakan bahwa ketika seseorang berbicara dengan penuh kebencian dan kemarahan, maka hal itu akan mengarah kepada ketidakbahagiaan dan rasa sakit serta penderitaan. Itulah sebabnya, pustakan Yajurveda 3,4 menyatakan bahwa seorang harus selalu berbicara lembut.

\section{Tidak Serakah (Alouptvam):}

Nilai karakter yang bermakna 'tidak serakah' (alouptvam) sebagai unsur ke enam belas dapat ditemukan dalam sloka Bhagavad Gita 16.2 ahiAsâ satyam akrodhas tyâga\% úântir apaioeunam dayâ bhûtecv alouptvaA mârdavaA hrîr acâpalam. Artinya: 'Nonkekerasan, kebenaran, ketiadaan kemarahan, renunsiasi, ketenangan, tidak memfitnah (mengumpat), welas asih kepada makhluk, tidak tamak, kelembutan, kerendahan hati, tidak berubah-ubah'. Sloka Bhagavad Gita 16.3 juga menyatakan bahwa ketidak-tamakan atau tidak serakah adalah sifat dari orang yang lahir dari kesucian'.

Ngakan Putu Putra menyatakan bahwa dalam ajaran Hindu, kama, krodha dan lobha, dikatakan sebagai tiga pintu gerbang neraka. Serakah adalah sifat dan sikap yang selalu hendak memiliki lebih dari yang dimiliki; sama artinya dengan lobha; tamak; rakus yang artinya meskipun sudah kaya, ia masih juga hendak mengangkangi harta saudaranya; (KBBI online). Dalam definisi ini serakah adalah kehendak atau tindakan untuk memiliki lebih banyak dengan merugikan orang lain. Mengapa serakah dianggap buruk? Karena serakah biasanya berpusat pada keinginan untuk mementingkan diri sendiri dan dalam memenuhi keinginan itu orang tidak perduli keperluan orang lain, sekalipun itu merugikan orang banyak. Serakah juga bisa merugikan diri sendiri. Orang yang makan dan minum tanpa kendali bisa membawa penyakit bagi dirinya. Orang yang menduduki berbagai jabatan juga dianggap serakah, karena dengan itu dia tidak memberi kesempatan orang lain untuk merealisasikan potensi dirinya. Oleh karena itu serakah dipandang buruk.

Ngakan Putu Putra lebih lanjut menyatakan bahwa keserakahan sangat dikutuk oleh semua tradisi agama besar, karena keserakahan mencegah kita dari gambaran yang lebih besar, karena menghalangi kita berkomunikasi dengan diri kita sendiri dan dengan Tuhan. Ketamakanlah yang membuat manusia melakukan dosa, ketamakan yang menyebabkan kemurkaan; ketamakan yang mengalir nafsu, ketamakan juga yang menyebabkan hilangnya penilaian yang benar, munculnya penipuan, kebanggaan, kesombongan, dan kedengkian, balas dendam, hilangnya rasa malu, hilangnya kebajikan, kecemasan, dan penghujatan, kikir, keinginan untuk setiap jenis tindakan yang tidak tepat, kebanggaan karena kelahiran, kebanggaan 
karena terpelajar, kebanggaan karena kecantikan, kebanggaan kekayaankekayaan, tanpa welas asih untuk semua makhluk, kedengkian terhadap semua ... (ibid).

Di dalam agama Hindu, artha atau kekayaan menjadi salah satu tujuan hidup. Tidak ada pembatasan berapa besar kekayaan itu boleh dicari. Yang ditentukan adalah bahwa artha itu harus dicari dan dipergunakan di jalan dharma. Kekayaan bukanlah tujuan pada dirinya sendiri, ia adalah untuk tujuan kesejahteraan manusia (abhyudaya). Dan ini bukanlah tujuan tertinggi. Tujuan tertinggi adalah moksa, persatuan jiwa dengan Tuhan. Untuk tujuan ini kekayaan harus dilepaskan. Mencari kekayaan adalah kewajiban pada tahap kita hidup sebagai perumah tangga (grihasta), dan setelah itu, ketika memasuki tahap hidup wanasrama, tahap hidup melepaskan kehidupan duniawi, kekayaan itu harus dilepaskan.

\section{Kedermawanan/Kemurah-hatian (Danam)}

Nilai karakter yang bermakna 'kedermawanan' atau 'kemurah-hatian' (danam) sebagai unsur ke tujuh belas dapat ditemukan dalam Bhagavad Gita 16.1 yang berbunyi: abhayaA sattva sanchuddhir jñâna yoga vyavasthiti\% dânaA damaúh cha yajñaúh cha svâdhyâyas tapa ârjavam' Artinya: 'Keberanian, kemurnian hati, ketekunan dalam ilmu pengetahuan, dan yoga, kedermawanan, pengendalian indera, yajna atau pengorbanan, mempelajari pustaka suci, hidup sederhana, kejujuran atau kelurusan hati' . Semua sifat-sifat tersebut muncul pada mereka yang lahir dari kesucian (Bhagavad Gita 16.3). Selain itu perihal kedermawanan juga terdapat dalam sloka 10.5; 17.7; 20-22; 18.5, 43).

Ngakan Putu Putra menyatakan kedermawanan tidak harus menjadi hak khusus orang kaya. Sesungguhnya orang-orang yang hidup sederhana, telah melakukan sifat kedermawananini, khususnya untuk lingkungan dekatnya, seperti keluarganya misalnya. Sebab danam juga berarti kemampuan untuk membagi kekayaan yang kita miliki kepada orang lain. Umat Hindu yang telah mencerna ajaran ini menjadi orang yang paling murah hati di dunia. Banyak orang Barat yang berbicara tentang kemurah-hatian orang India. Hal ini karena mereka telah diajarkan tentang dana ini. Konsep tentang danam ini adalah ide yang indah, yang berarti 'saya mempunyai sesuatu'; 'anda memerlukan sesuatu'; maka ini saya berikan kepada anda'. Seluruhnya dilakukan secara alamiah. Itulah aspek dari konsep dana menjadi bagian dari daivi sampat 'sifat kedewataan'

\section{Berterima Kasih ( $\underline{\text { Krtajñatâ }})$.}

Nilai karakter yang mengandung makna 'berterima kasih' sebagai unsur ke delapan belas secara tidak langsung berhubungan dengan sloka Bhagavad Gita 3.13, yang bunyi sbb: yajnasishtasinah santo, mucyante sarva-kilbishaih, bhunjate te tv agham papa ye pacanty atma-karanat' Artinya: 'Orang-orang yang makan sisa-sisa persembahan dibebaskan dari segala dosa; sedangkan mereka yang memasak makanan (hanya) untuk kepentingan mereka sendiri, maka sesungguhnya mereka memakan dosa'. Sloka ini sesungguhnya mengajarkan orang agar memiliki rasa syukur atau terima kasih (kItajñatâ). Sebab makanan yang dimakan itu sesungguhnya adalah anugerah Tuhan, karena Tuhanlah yang menciptakan makanan.

Ngakan Putu Putra menyatakan mengucapkan terima kasih tidak perlu biaya atau upaya apapun. Yang diperlukan adalah ketulusan hati atau sikap lascarya. Tanpa itu ucapan terima kasih akan tergelincir jadi sekedar mekanis dan basa-basi. Berterima kasih (gratitude) adalah keutamaan yang penting, karena itu ia dibahas oleh para filsuf dan juga diperintahkan oleh agama. Satguru Sivaya Subramuniya Swami, pendiri Ashram Hindu di Hawaii dan pendiri majalah Hinduism Today, dalam tulisannya: Two Powers: 
menyatakan bahwa ada dua kekuatan, yaitu: Terima Kasih dan Penghargaan, rasa terima kasih adalah kualitas jiwa. Hal ini tidak tergantung pada berapa banyak yang kita miliki. Lawannya adalah tidak tahu berterima kasih, ini adalah kualitas ego eksternal. Ketika kita tinggal di dalam kesadaran jiwa, kita berterima kasih untuk apa pun yang kita miliki, tidak peduli seberapa kecil atau seberapa banyak. Ketika dalam kesadaran ego, kita tidak pernah berterima kasih atau puas, tidak peduli berapa banyak yang kita miliki.

Ngakan Putu Putra juga menambahkan bahwa berterima kasih dan menyampaikan penghargaan adalah kata kunci untuk kehidupan yang lebih baik. Mereka adalah mantra yang diucapkan untuk melarutkan kebencian, sakit hati dan kesedihan, obat yang menyembuhkan keadaan pikiran subjektif, memulihkan rasa hormat diri, kepercayaan dan keamanan. Satguru Sivaya Subramaniya mengatakan, rasa terima kasih adalah sadhana, atau praktik spiritual. Rasa terima kasih adalah perasaan dalam hati yang tidak dapat ditekan lama ketika diatasi dengan kenangan yang melimpah dari semua kebaikan yang telah datang ke dalam hidup kita. Karena itulah membiasakan mengucapkan terima kasih dan penghargaan adalah unsur yang dapat membangun karakter yang mulia.

\section{Bersih, Murni, Suci (Saucam):}

Nilai karakter yang bermakna 'bersih, murni, dan suci (saucam) sebagai unsur ke sembilan belas dapat ditemukan dalam Bhagavad Gita 16.3 sebagaimana dinyatakan: teja\% kcamâ dh[ti\% úaucam adroho nâtimânitâ bhavanti sampadaA daivîm abhijâtasya bhârata. Artinya: Semangat, vitalitas, pengampunan, ketabahan, kebersihan, bebas dari rasa iri dan semangat untuk menghormati-sifat-sifat transendental, $\mathrm{O}$ putra Bharata, milik manusia yang dikaruniai dengan sifat kedewataan. Kata saucam juga terdapat dalam lima sloka Bhagawad Gita lainnya yaitu: 13,$7 ; 16.3,7 ; 17.14 ; 18.42$ )

Ngakan Putu Putra menyatakan bahwa kata saucam meliputi konsep yang luas, menyangkut kebersihan tubuh, lingkungan, pikiran, perkataan dan perbuatan; bahkan alatalat yang digunakan untuk memasak dan makan. Saucam atau sauca (kemurnian, kesucian) dicatat oleh Rsi Patanjali dalam Yoga Sutra (200 SM) sebagai satu dari lima disiplin di bawah Niyama, yang kedua dari delapan langkah yoga. Saucam terdiri dari dua jenis: bhaya atau eksternal; antara atau internal. Yang pertama dicapai dengan membersihkan badan dan yang kedua dengan menaklukkan enam musuh di dalam diri seperti nafsu dan keserakahan. Sauca dianggap sebagai salah satu dari elemen penting dalam menjalani hidup Dharma. Pustaka Suci Hindu berkali-kali menekankan pentingnya sauca. Dalam Daksa Smriti dinyatakan bahwa seseorang harus selalu mencoba mempertahankan sauca dalam pekerjaan apa pun. Ia yang tanpa kepatuhan akan kemurnian, semua tindakan dan kerja menjadi sia-sia. Sauca secara harfiah berarti kebersihan juga kemurnian. Kebersihan mengacu kepada yang eksternal, sedangkan kemurnian kepada yang internal (sakala dan niskala).

Ngakan Putu Putra menambahklan bahwa hanya dengan mempraktikkan ajaran dharma seperti satya, asteya, tapas dll. seseorang mampu mengatasi nafsu dan gairah internal lainnya dan mencapai chitta-shuddhi (pemurnian pikiran) yang diperlukan untuk mencapai realisasi-Diri. Dan Realisasi-diri ini adalah tujuan akhir dari praktik sauca. Karena itu sauca merupakan landasan untuk membentuk karakter yang mulia.

\section{Tarak, Pantangan Seksual (Brahma- charya):}

Nilai karakter yang memiliki makna 'tarak, pantang seksual' (brahmacharya) sebagai 
unsur ke dua puluh dapat ditemukan dalam sloka Bhagavad Gita 17.14 dan juga sloka lainnya, sebagaimana dinyatakan: Deva dvija guru prâjña pûjanamì úaucam ârjavam brahmacaryam ahimìsâ ca úârîramì tapa ucyate. Artinya: 'Pemujaan Tuhan, mereka yang lahir dua kali, guru spiritual dan orang bijaksana, kebersihan, kesederhanaan, bertarak (pantang seksual) dan antikekerasan disebut tapa badan. Selain itu brahmacharya juga disebut dalam sloka Bhagavad Gita 8.11. Ngakan Putu Putra menyatakan bahwa brahmacaryam, 'tarak' (pantang seksual), adalah penahanan diri dalam kehidupan fisik. Brahmachari sendiri artinya adalah masa belajar (tentang Tuhan). Tahap pertama dari asrama (empat tahapan hidup). Pada periode ini bertarak atau berpantang melakukan hubungan seksual diwajibkan, karena energi seksual akan disublimasi menjadi ojah (ojas), yang arti literalnya adalah: vitalitas, cahaya, kilau, energi, energi spiritual; cairan seksual yang dikonversi menjadi ojas dalam praktik yog a berkelanjutan. Menurut Weda, seorang yang melakukan pantangan seksual akan memiliki ketajaman pikiran, kekuatan spiritual, kesehatan dan akan memperoleh ilmu yang membuat manusia bahagia. Itulah sebabnya sehingga bertarak atau melakukan kehidupan brahmachari itu dianggap sebagai dasar dari pembentukan karakter

\section{Menundukkan Nafsu (Vairagya):}

Nilai karakter yang mengandung makna 'menundukkan hawa nafsu' (vairagya) sebagai unsur ke dua puluh satu dapat dijumpai dalam sloka Bhagavad Gita 6.35 sebagaimana dinyatakan: asamsayam maha-baho mano durnigraham calam; abhyasena tu kaunteya vairagyena ca grhyate Artinya: Tidak diragukan lagi, $\mathrm{O}$ yang bersenjata perkasa, pikiran itu gelisah dan sangat sulit untuk dikendalikan, tapi melalui praktik dan renunsiasi, O Putra Kunti, itu dapat dicapai. Selain itu vairagya juga terdapat dalam sloka Bhagavad
Gita 13,8, 18,52 dan tyaga disebut dalam sloka Bhagavad Gita 18.1.

Vairagya sesungguhnya lebih mengacu kepada keadaan internal pikiran daripada gaya hidup eksternal dan dapat dipraktikkan sama baiknya oleh seorang yang terlibat dalam kehidupan keluarga (rumah tangga) dan karir sama baiknya dengan mereka yang melepaskan keduniawian. Ngakan Putu Putra menyatakan bahwa vairagya bukan berarti penindasan atau mengembangkan penolakan atau kejijikan pada obyek material. Dengan penerapan viveka (diskriminasi atau kebijaksanaan spiritual) untuk pengalaman hidup. Melalui vairagya calon spiritual secara bertahap mengembangkan daya tarik yang kuat pada sumber spiritual dalam pemenuhan dan kebahagiaan dan semua keterikatan terbatas jatuh secara alami. Keseimbangan dipertahankan antara keadaan spiritual batin dan kehidupan eksternal atau duniawi seseorang melalui praktik melihat semua entitas yang terbatas sebagai ekspresi terbatas dari Kesadaran Kosmis atau Brahman yang tunggal. Karena itulah vairagya ini dipandang penting sebagai unsur pembentuk karakter.

\section{Kesabaran (Ksantih):}

Nilai karakter yang bermakna 'kesabaran (ksantih) sebagai unsur ke dua puluh dua dapat ditemukan dalam sloka Bhagavad Gita 13.7 sebagaimana dinyatakan: amâni tvam adambhitvam ahimisâ ksòântir ârjavam; âcâryopâsanamì eaucamì sthairyam âtma-vinigrahahò. Artinya 'Kerendahan hati; tidak sombong; antikekerasan; kesabaran; kejujuran; pelayanan kepada guru spiritual; kebersihan; kemantapan; pengendalian diri'. Semua itu dinyatakan sebagai pengetahuan (13.11). Selain itu juga ssantih juga disebut dalam sloka 2.41dan 18.42.

Ngakan Putu Putra menyatakan bahwa: makna kesabaran itu dekat sekali dengan makna pengampunan. Interpretasi dan praktek 
pengampunan Gandhi benar-benar selaras dengan tradisi Hindu dan Jain. Sesungguhnya, perspektif spiritualnya dapat dipahami dengan baik melalui tiga prisma, yaitu: (1) Pengampunan sebagai suatu kebajikan, bersama keutamaan lain seperti dana atau amal. (2) Pengampunan sebagai komponen kekuatan spiritual, dan (3) Pengampunan sebagai sarana untuk regenerasi masyarakat. Daftar 'sifat kedewataan' dari Bhagawad Gita (16.3) berfungsi sebagai pengingat yang baik tentang keutamaan atau kebajikan untuk orang yang bercita-cita spiritual, dan beberapa dari pernyataan Gandhi tentang pengampunan dikutip dari Bhagavad Gita dan pustaka Mahabharata.

Ngakan Putu Putra juga menguraikan bahwa kesabaran adalah keadaan daya tahan dalam situasi sulit, yang bisa berarti tekun atau gigih dalam menghadapi keterlambatan atau provokasi tanpa bertindak secara negatif, jengkel atau marah; atau menunjukkan kesabaran ketika berada di bawah tekanan, terutama ketika menghadapi kesulitan jangka panjang. Kesabaran adalah tingkat ketahanan yang bisa dilakukan dalam menghadapi tindakan atau keadaan negatif. Kesabaran juga digunakan untuk merujuk pada sifat karakter yang teguh. Kesabaran dianggap sebagai kebajikan utama dalam Hindu Dharma (Encyclopaedia Britannica, 2009). Dalam literatur kuno Hindu, konsep kesabaran disebut juga dengan kata pariksaha dan beberapa kata lainnya seperti sahicGutâ (toleransi), titiksha, sah atau sahanshilta (menderita dengan kesabaran) dan beberapa kata lain.

Kesabaran, dalam filsafat Hindu, adalah ketahanan (daya tahan) ceria menghadapi kondisi yang sulit dan konsekuensi dari tindakan atau perbuatan (karma). Kesabaran juga kemampuan untuk menunggu, bertahan terhadap hal-hal yang berlawanan ( $d v a n d v a$, rwa bhineda) - seperti rasa sakit dan senang, dingin dan panas, kesedihan dan sukacita dengan tenang, tanpa kecemasan, dan tanpa keinginan untuk membalas dendam. Dalam hubungan interpersonal, keutamaan kesabaran berarti bahwa jika seseorang menyerang atau menghina kita tanpa sebab, kita harus menanggungnya tanpa merasa permusuhan, kemarahan, kebencian atau kecemasan. Karena itu kesabaran menjadi pondasi karakter.

\section{Pengampunan (Ksama):}

Nilai karakter yang mengandung makna 'pengampunan' (ksama) sebagai unsur ke dua puluh tiga dapat ditemukan dalam sloka Bhagavad Gita 16.3 yang berbunyi: teja\% kcamâ dh[ti\% úaucam adroho nâti-mânitâ bhavanti sampadaA daivîm abhijâtasya bhârata. Artinya: 'Kekuatan, pengampunan, ketabahan, kebersihan, kebebasan dari rasa iri dan semangat untuk menghormati-sifat-sifat transendental, O putra Bharata, milik manusia yang dikaruniai dengan sifat kedewataan'. Selain itu, kata ksama juga disebut dalam sloka 10.4 .

Ngakan Putu Putra menyatakan bahwa pengampunan atau pemaafan adalah proses yang disengaja dan sukarela di mana korban mengalami perubahan perasaan dan sikap tentang suatu pelanggaran, melepaskan emosi negatif seperti dendam, dengan peningkatan kemampuan untuk mengharapkan pelaku akan baik-baik saja. Mengampuni dianggap sebagai salah satu kebajikan utama dalam Hindu Dharma. Manusia pengampun, mendapatkan wilayah yang banyak dipuja yang ada di dunia Brahma atau di alam moksha. Pengampunan adalah kekuatan yang perkasa; pengampunan adalah pengorbanan; pengampunan adalah pikiran yang tenang. Itulah sebabnya, pengampunan merupakan tonggak pembangunan karakter.

\section{Welas Asih (Karuna):}

Nilai karakter yang mengandung makna welas asih (karuna) sebagai unsur ke dua puluh empat dapat ditemukan dalam sloka Bhagavad Gita 12.13-14 sebagaimana 
dinyatakan: advesòtòâ sarva- bhûtânâmì maitrahò karunòa eva ca ; nirmamo nirahañkârahò sama duhòkha

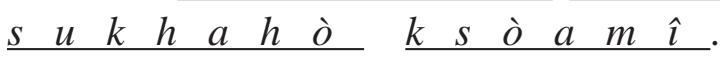

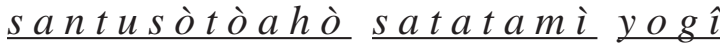
yatâtmâ dròdòha-nioccayahò mayy arpita manobuddhir yo mad-bhaktahò sa me priyahò. Artinya: 'Dia yang tidak membenci semua makhluk, dan berteman baik dan penuh welas asih terhadap semua, yang bebas dari perasaan "Aku dan milikku", berpikir sama dalam sakit dan senang, sabar. Selalu puas, mantap dalam meditasi, mengendalikan diri, dan memiliki keyakinan kuat, dengan pikiran dan kecerdasan tetap pada-Ku, orang yang demikian berbhakti pada-Ku, maka ia yang $\mathrm{Ku}$ sayangi.

Ngakan Putu Putra menjelaskan bahwa sifat welas asih merupakan komponen kunci yang dalam konteks sosial sebagai altruisme (mementingkan kepentingan orang lain). Dalam hal etika, ekspresinya selama berabad-abad disebut sebagai Aturan Emas (Golden Rule) yang sering diwujudkan oleh prinsip kasih sayang, sebagaimana ungkapan "lakukan kepada orang lain apa yang akan anda harapkan orang lain akan lakukan untuk anda". Hal ini jelas merupakan perwujudan dari ajaran Tat tvam asi.

Ngakan Putu Putra menyatakan bahwa Mahatma Gandhi juga membandingkan welas asih Yesus dengan Sang Buddha. Menurut Gandhi welas asih sang Buddha jauh lebih luas daripada welas asih Yesus. Karena welas asih Yesus hanya terbatas pada manusia yang beriman kepadanya. Sedangkan welas asih Sang Buddha meliputi semua makhluk, tak perduli mereka percaya atau tidak pada Dirinya. Ajaran welas asih dalam Bhagawad Gita dan juga dalam Weda, ditujukan kepada semua makhluk (sarva bhuta), tidak hanya kepada manusia saja, apalagi manusia dengan indentitas agama tertentu saja.

\section{Pertemanan (Maitri):}

Nilai karakter yang bermakna 'pertemanan (maitri) sebagai unsur ke dua puluh lima pembentuk karakter dapat ditemukan dalam Bhagavad Gita 12.13 sebagaimana dinyatakan: advesòtòâ sarva-bhûtânâmì maitrahò karunòa eva ca ; nirmamo nirahañkârahò sama-duhòkhasukhahò ksòamî. Artinya: 'Dia yang tidak membenci apa dan siapa saja serta berteman baik dengan segala makhluk, penuh kasih sayang terhadap semua mahluk, bebas dari perasaan "Aku dan milikku", berpikir sama dalam susah dan senang, sabar'. Semua hal itu yang dimiliki oleh orang seperti itu, adalah orang yang sangat Ku-sayangi (Bhagavad Gita 12.14)

Ngakan Putu Putra menyatakan bahwa kesetiaan kepada 'seseorang yang nyatanyatanya telah mengkhianati amanah yang pernah diberikan publik padanya' mengandung potensi bahaya. Bila seandainya politisi Bali ini menjadi pejabat tinggi yang memiliki kekuasaan besar, mungkin dia akan membebaskan gurunya yang telah mengkhianati amanah publik dari semua kesalahan, karena dalam pandangannya Anas telah diperlakukan tidak adil, dizolimi. Atau kalau ada teman baiknya yang melakukan korupsi dia akan membelanya.

Tentu saja kita harus tetap setiap kepada teman, sekalipun teman itu kemudian berdasarkan keputusan pengadilan dinyatakan sebagai kriminal. Tetapi fungsi seorang teman dalam situasi ini adalah memberi penghiburan, dan kalau mungkin mendorongnya mulai melakukan introspeksi untuk menyadari kekeliruannya. Bukan memberi pem-belaan yang terkesan membabi buta, atau membuatbuat teori konspirasi. Ini hanya akan membesar-besarkan ego temannya dan membuat dia semakin jauh dari kebenaran dan sulit menyesali kesalahannya. Pertemanan tidak hanya menjadi dasar hubungan baik antara 
anggota masyarakat, tetapi juga menjadi dasar bagi perkawinan yang langgeng. Itulah sebabnya pertemanan menjadi salah satu pondasi pembangunan karakter.

\section{Kelemah-lembutan (Mardawam):}

Nilai karakter yang bermakna 'kelemahlembutan' (mardawam) sebagai unsur ke dua puluh enam pembentuk karakter dapat ditemukan dalam sloka Bhagavad Gita 16.2 sebagaimana dinyatakan: ahiAsâ satyam akrodhah tyâga\% úântir apaicunam dayâ bhûtecv aloluptvaA mârdavaA hrîr acâpalam'. Artinya: 'Tanpa kekerasan, kebenaran, ketiadaan-kemarahan, renunsiasi, ketenangan, tidak memfitnah, welas asih kepada seluruh makhluk, tidak tamak, memiliki kelembutan, memiliki kerendahan hati, tidak konsisten atau berubah-ubah'. Semuanya itu adalah sifat-sifat dari mereka yang lahir dari kesucian (Bhagavad Gita 16.3)

Ngakan Putu Putra mengatakan bahwa kelemah-lembutan dianggap sebagai salah satu unsur keutamaan yang membentuk karakter, karena karakter seorang kokoh harus seperti batu karang, yang akan mampu tetap berdiri tegak menghadapi kehidupan yang penuh persaingan keras. Kelemah-lembutan terlalu feminine, tetapi tidak boleh lupa bahwa manusia memulai hidup di dunia ini dengan kelemahlembutan. Manusia lahir dalam keadaan lemah dan tulang-tulangnya masih lembut. Kelemahlembutan para orang tua, terutama ibu yang melindungi anak-anaknya, memberi susu, makan, memandikan, mengobati, menggendong menemani tidur. Kelemah-lembutan itulah yang memelihara setiap oaring sampai bisa berjalan sendiri.

Ngakan Putu Putra menambahkan bahwa melaluyi kelemah-lembutan inilah lahir kualitaskualitas welas asih, kesabaran, pengampunan, tanpa kekerasan, pertemanan, penghormatan terhadap kehidupan. Tanpa kualitas-kualitas ini, yang sekarang disebut sebagai keutamaan atau kebajikan, manusia bisa menjadi binatang buas atau teroris yang sangat kejam. Itulah sebabnya kelemah-lembutan menjadi unsur pembentuk karakter.

\section{Damai atauTenang (Shanti)}

Nilai karakter yang bermakna 'damai' atau 'tenang' sebagai unsur ke dua puluh tujuh pembentuk karakter dalam karya Ngakan Putu Putra dapat ditemukan dalam Bhagavad Gita 16.2 sebagaimana dinyatakan: ahiAsâ satyam akrodhah tyâga\% úântir apaiœunam dayâ bhûtecv aloluptvaA mârdavaA hrîr acâpalam'. Artinya 'tanpa kekerasan, kebenaran, ketiadaan kemarahan, renunsiasi, kedamaian, tidak memfitnah (mengumpat), welas asih kepada makhluk, tidak tamak, kelembutan, kerendahan hati, konsisten atau tidak berubah-ubah'. Semua itu adalah sifatsifat dari mereka yang lahir dari kesucian' (Bhagavad Gita 16.3). Ngakan Putu Putra menulis "Jika kemanusiaan ingin bergerak maju, maka manusia harus berupaya menghidupi, memikirkan, bertindak dan terinspirasi oleh visi kemanusiaan yang berkembang menuju dunia yang damai dan harmonis." Demikian dikatakan oleh Dr Martin Luther King, Jr., tokoh perjuangan hak-hak sipil warga kulit hitam di AS yang menggunakanm metode perjuangannya mengikuti metode ahimsa dan satyaraghanya Gandhi.

Selanjutnya Ngakan Putu Putra menyatakan bahwa kedamaian batin (atau ketenangan pikiran) adalah suatu keadaan yang mengacu pada suatu keadaan mental dan spiritual damai, dengan pengetahuan yang cukup dan pemahaman untuk menjaga diri yang kuat dalam menghadapi perselisihan atau stres. Menjadi "damai" dianggap oleh banyak orang untuk menjadi homeostasis (suatu kondisi keseimbangan internal yang ideal, di mana semua sistem tubuh bekerja dan berinteraksi dalam cara yang tepat untuk memenuhi semua kebutuhan dari tubuh) sehat dan kebalikan dari stres atau cemas. Ketenangan pikiran umumnya dikaitkan dengan kebahagiaan. 
Demikianlah dua puluh tujuh unsur-unsur keutamaan yang digali oleh Ngakan Putu Putra dalam Bhagavad Gita sebagai unsur-unsur yang menjamin terbentuknya karakter mulia. Dari berbagai literatur sejenis yang dikumpulkan tampaknya karya Ngakan Putu Putra ini merupakan karya terbesar. Karena alasan itu maka studi pustakan ini dilakukan.

\section{SIMPULAN}

Melalui analisis terhadap beberapa literature sebagaimana tercatum dalam daftar bacaan (daftar pustaka), dengan membandingkan cakupan dan pemaparan dari semua pusataka tersebut, dapat ditarik kesimpulan bahwa dua puluh tujuh nilai keutamaan Bhagawad Gita yaitu (1) Kejujuran; (2) Kebenaran; (3) Keberanian; (4) Kepahlawanan; (5) Tahan Uji, (6) Ketabahan; (7) Ketetapan Hati; (8) Hidup Sederhana; (9) Hidup Penuh Semangat; (10) Pengendalian Diri; (11) Kebijaksanaan Yang Mantap; (11) Tidak Mencari-cari Kesalahan Orang Lain; (12) Rendah hati, Bersahaja; (13) Tanpa-kekerasan; (14) Tidak Membenci; (15) Tidak Marah; (16) Tidak Serakah; (17) Kedermawanan; (18) Berterima Kasih; (19) Kemurnian atau kesucian; (20) Pantang Seksual; (21) Menundukkan Nafsu; (22) Kesabaran; (23) Pengampunan; (24) Welas Asih; (25) Pertemanan; (26) Kelemah-lembutan; (27) Kedamaian, hasil temuan Ngakan Putu Putra dalam penelitiannya terhadap Bhagavad Gita dapat memberi jaminan kepada bangsa Indonesia terbentuknya karakter sesuai harapan Pemerintah Indonesia untuk menjadi bangsa dengan peradaban paling unggul di muka bumi.

\section{DAFTAR PUSTAKA}

Baba, Bhagavan Sri Sathya, 1988. Discourses on the Bhagavad Gita, Andhra Pradesh: Sri Sathya Sai Books and Publication Trust
Darmayasa, 2014. Bhagavad Gîtâ (Nyanyian Tuhan), Denpasar: Yayasan Dharma Sthapana

Donder, I Ketut, 2004. Sisya Sista: Pedoman Menjadi Siswa Mulia, Surabaya: Paramita

Donder, I Ketut, 2008. Acharya Sista: Guru dan Dosen yang Bijaksana, Surabaya: Paramita

Krishna, Ananda, 2015. Bhagavad Gîtâ Bagi Orang Modern, Jakarta: Gramedia

Maswinara, I Wayan, 1997. Srimad Bhagavad Gîtâ, Surabaya: Paramita

Prabhupada, A.C. Bhaktivedanta Swami, 1968, The Science of Self-Realization, Mumbai: The Bhaktivedanta Book Trust

Prabhupada, Swami. 1986. Bhagawad Gîtâ Menurut Aslinya (Bhagavadgita As It Is), Jakarta : Yayasan Bhaktivedanta

Prabhupada, Swami. 1998. Bhagavad Gîtâ As It Is, Mumbai: The Bhaktivedanta Book Trust

Putra, Ngakan Putu, 2016. Membangun Karakter Dengan Keutamaan Bhagavad Gita, Jakarta: Media Hindu

Hoery dan Farih, 2013. Memandirikan Generasi Emas Indonesia, Info Muria/ Edisi XIV/ Mei-Juli 2013: Kudus Universitas Muria Kudus

Prasetyo, Zuhdan K. 2014. Generasi Emas 2045 sebagai Fondasi Mewujudkan Siklus Peradaban Bangsa Melalui Implementasi Kurikulum 2013 di Sekolah Dasar, Yogyakarta: Universitas Negeri Yogyakarta zuhdan@uny.ac.id 